\title{
INFLUENCE OF PRE-CROPS ON WEEDY COMPONENT OF AGROPHYTOCENOSIS IN CULTIVATION OF WINTER WHEAT UNDER NO-TILLAGE TECHNOLOGY
}

\author{
Vera Perederieva, Olga Vlasova, Irina Wolters, Anna Shutko
}

Stavropol State Agrarian University, Russia

perederieva@yandex.ru, olastgau@mail.ru, volters06@rambler.ru, schutko.an@yandex.ru

\begin{abstract}
The exclusion of mechanical tillage leads to the concentration of seeds on the surface under plant residues and in the upper soil layer. In the period of full ripeness of pre-crops, before their harvesting, the potential of weed seeds in the $0-5 \mathrm{~cm}$ layer after winter rape is $36.9 \%$ lower than after corn for grain and $44.3 \%$ compared to sunflower. A longer post-harvest period after winter rape helps clear the top layer of the soil from weed seeds to sowing winter wheat by $30.8 \%$. The lack of a time interval from harvesting of sunflower and corn before sowing of winter wheat leads to the accumulation of weed seeds in the $0-5 \mathrm{~cm}$ layer.At this time the culture is marked by negative dynamics of infestation of the top layer. This process takes place more intensively after winter rape and is $47.2 \%$. With deepening in the soil to $10 \mathrm{~cm}$, the number of weed seeds is reduced. Use of no-tillage technology changes the formation of agrophytocenosis of winter wheat. After the predecessor of winter rape in the tillering phase, the number of weeds is reduced by $34.1 \%$ compared to sunflower and by $47.1 \%$ - to corn. Different efficiency of pre-crops in the reduction of weed populations can be traced in the future during the growing season of winter wheat. In the period ofwinter wheat earing, the contamination of crops is significantly reduced for all pre-crops.But it is not only the result of chemical weeding carried out in the tillering phase, but also real competition of the culture itself, as there is an increase in its vegetative mass. Weeds in this period have a small mass, little different in pre-crops, located in the range from 9.3 to $12.2 \mathrm{~g} \mathrm{~m}^{-2}$. To the full ripeness of winter wheat, the contamination of crops increases and this is due to the "clarification" of crops, when the culture no longer competes with weeds. During this period, the pattern established bythe pre-crops in the previous phase remains.
\end{abstract}

Keywords: no-tillage technology, winter wheat, pre-crops, weeds.

\section{Introduction}

The problem of maintaining a favorable phytosanitary condition of crops remains one of the most important issues in agricultural practice. Successful management of weed species depends not only on control of their size and weight in crops, but also the control of seeds and organs of vegetative reproduction in the soil. The existence of this reserve with combination of biological properties, such as high fecundity, viability, longevity, polymorphism explains the stability of species composition of weeds and annual renewal in the fields. Technological methods used in crop production significantly affect the number and biodiversity of weed seeds in the soil and vegetative plants in agrophytocenosis. In modern agriculture of Russia a new direction is being implemented and is becoming increasingly widespread - cultivation of crops without tillage. The use of no-till technology contributes to the accumulation of moisture in the soil, improving the agrophysical properties, saving energy and material resources $[1 ; 2]$. However, there is a danger of deterioration of the phytosanitary condition of crops, or an increase of their contamination. In the agrophytocenoses of field crops, as a rule, there are two components - cultural and weed plants. Field crops are the dominant, and all elements of the technology are aimed at creating optimal conditions for their growth, development and effective use of life factors [3]. Weeds, in contrast to cultivated plants, have a high adaptive potential for habitat in agrocenoses and resist intensive anthropogenic impact. The range of the existing techniques in the practice of agriculture that involves tillage, crop rotations, use of herbicides, allows adjusting the number of weeds at which they are not able to significantly reduce the yield of cultivated plants [4-6]. Elimination of mechanical tillage to no-till technology increases the role of other factors, among whichthepre-crops play an important role in managing contamination of soil and crops given.

\section{Material and methods}

A comparative assessment of the winter wheat pre-crops was carried out in 2017-2018 under production conditions with the allocation of control zones in the farm, located in the region of unstable humidification of the Stavropol Territory. The climate is characterized as continental with moderate humidification (SCC 0.9-1.1). The average long-term amount of precipitation is $506 \mathrm{~mm}$. The soil coveris represented by ordinary chernozem and is typical for the zone of unstable moistening. The object of the research was winter wheat in crop rotation after the pre-crops of winter rapeseed, corn for 
grain and sunflower. According to the no-till technology, herbicides against weeds were used twice: after harvesting the forecrops - Roundup, BP with a consumption rate of $31 \cdot \mathrm{ha}^{-1}$ for $1-5$ days before sowing with a sprayer John Deer 4630; in spring in the tillering phase of winter wheat - Tifens, VDG with a consumption rate of $10 \mathrm{~g} \cdot \mathrm{ha}^{-1}+$ Artstar, VDG with a consumption rate of $10 \mathrm{~g} \cdot \mathrm{ha}^{-1}$.

The potential soil contamination by seeds was determined during the period of full ripeness of the pre-crops before sowing and during the heading of winter wheat. Soil samples were taken by a soil auger to a depth of $0-5 \mathrm{~cm}$ and $5-10 \mathrm{~cm}$. The weediness of crops was taken into account by the quantitative-weight method in the tillering stages, earing and full ripeness of winter wheat [7].

\section{Results and discussion}

Weeds are the most harmful and common group of pests. High contamination of crops causes large-scale annual application of herbicides, which complicates the ecological situation. The main source of weed infestation is weed seeds in the soil, most of which germinate from a small depth of 0 to $5 \mathrm{~cm}$. In the absence of soil treatments with no-till technology, weed seeds remain on the soil surface. In this connection, the potential of seeds in the upper layer and its regulation due to the scientifically-based alternation of crops is of practical importance. During the period of full ripeness of the pre-crops of winter wheat, before they were harvested, a different stock of weed seeds was installed in the soil layer of $0-10 \mathrm{~cm}$. After sunflower, the number of seeds reaches 102.8 million pcs $\cdot$ ha $^{-1}$, which is $7.4 \%$ higher than after corn grain and by $31.3 \%$ compared with winter rape (Table 1).

Table 1

Influence of winter wheat pre-crops on the potential reserve of weed seeds in the soil,mln.pcsha ${ }^{-1}$

\begin{tabular}{|c|c|c|c|c|c|c|}
\hline \multirow{2}{*}{$\begin{array}{c}\text { Previous } \\
\text { culture }\end{array}$} & \multicolumn{9}{|c|}{ Full ripeness of crops } & \multicolumn{3}{|c|}{$\begin{array}{c}\text { Before sowing winter } \\
\text { wheat }\end{array}$} & \multicolumn{2}{c|}{ Earing of winter wheat } \\
\cline { 2 - 7 } & $0-5$ & $5-10$ & $0-5$ & $5-10$ & $0-5$ & $5-10$ \\
\cline { 2 - 7 } & 48.5 & 22.2 & 33.6 & 18.2 & 25.6 & 11.3 \\
\hline Winter rapeseed & 76.8 & 18.4 & 73.6 & 18.1 & 51.0 & 9.3 \\
\hline Corn for grain & 87.1 & 15.7 & 80.3 & 15.3 & 64.4 & 8.6 \\
\hline Sunflower & 14.8 & 2.3 & 19.3 & 1.3 & 14.1 & 1.0 \\
\hline $\begin{array}{c}\text { LSD }_{0,05} \text {,mln. } \\
\text { pcsha }^{-1}\end{array}$ & &
\end{tabular}

Winter rape is a culture of continuous sowing, which has a high competitiveness for weeds during the growing season, suppressing their quantity, biomass, species composition and fecundity [8]. Sunflower and maize for grain are cultivated with wide row spacing, which leads to a decrease in the ability to resist weeds and affects their seed productivity and soil contamination. Of the total number of weed seeds, a layer of 0-10 cm after late-harvested tilled precursors from the surface and up to $5 \mathrm{~cm}$ of soil are concentrated from $80.6 \%$ to $84.7 \%$ of the seeds. After winter rape, this figure is $68.6 \%$. During the period of full ripeness of the previous crops, the potential of weed seeds in a layer of $0-5$ $\mathrm{cm}$ after winter rape is $36,9 \%$ lower than after corn for grain and $44.3 \%$ compared tosunflower.

The seed potential in the soil is not constant. In the soil, natural cleansing of weed seeds stocks occurs due to their aging and loss of viability under the influence of environmental factors. The precrops in a certain way change the soil habitat, as they affect the microbiological activity, humidity, aeration and temperature [9].

The influence of pre-crops on the number of weed seeds in the soil is preserved in dynamics. At the same time, a pattern was established that after winter rapeseed for winter wheat sowing, the stock of weed seeds in the $0-5 \mathrm{~cm}$ layer decreases by $30.8 \%$, exceeding the intensity of this process after corn for silage by $26.6 \%$, after sunflower by $22.9 \%$. The absence of a time interval from the harvesting of late- harvested row tillage pre-crops to the sowing of winter wheat explains the low loss of weed seeds. By the middle of the growing season, in the earing phase of winter wheat, the influence of the precursors on the seed potential is preserved; the process of their loss goes down more intensively after winter rape and amounts to $47.2 \%$ of the initial quantity. The predecessor forms a favorable environment for germination and subsequent destruction of weeds. With an increase in the 
depth up to $10 \mathrm{~cm}$, the difference in the effect of the precursors on the potential of the seeds decreases. After winter rapeseed and corn for grain over the entire study period the stock of weed seeds decreased by $49.1-49.5 \%$ and after sunflower, by $45.3 \%$.

Correctly chosen alternation of crops in crop rotation does not require additional energy and economic resources, and, at the same time, it is an effective means of regulating the weediness of crops. The use of no-till technology significantly changes the formation of agrophytocenoses of agricultural crops. The exclusion of mechanical tillage and movement of seeds in the plowed layer, lead to the concentration of seed reserves on the soil surface under the remnants or in the top layer of the soil by mixing them with the soil during heavy rains, snow melting, burrowing animals. As it is known, the bulk of weed seeds germinates from the top layer of $0-5 \mathrm{~cm}$.

A more contrasting effect of precursors on the weedy component of agrophytocenosis is traced in the tillering phase of winter wheat. Placing winter wheat in crop rotation after winter rapeseed helps reduce crop debris by $34.1 \%$ compared with sunflower and by $47.1 \%$ with corn for grain (Table 2 ).

Table2

Effect of pre-crops on weed infestation of winter wheat during the growingseason

\begin{tabular}{|c|c|c|c|c|c|c|}
\hline \multirow{2}{*}{$\begin{array}{l}\text { Previous } \\
\text { culture }\end{array}$} & \multicolumn{3}{|c|}{ Number of weeds, pcs $\cdot \mathrm{m}^{-2}$} & \multicolumn{3}{|c|}{ Biomass of weeds, $g \cdot \mathbf{m}^{-2}$} \\
\hline & tillering & earing & $\begin{array}{c}\text { full } \\
\text { ripeness }\end{array}$ & tillering & earing & $\begin{array}{c}\text { full } \\
\text { ripeness }\end{array}$ \\
\hline Winter rapeseed & 85 & 3 & 8 & 55.2 & 10.4 & 26.5 \\
\hline Cornfor grain & 125 & 5 & 26 & 89.7 & 9.3 & 81.3 \\
\hline Sunflower & 114 & 11 & 17 & 98.9 & 12.2 & 36.7 \\
\hline $\mathrm{HCP}_{05}$ & 8 & 4 & 13 & 10.4 & 0.2 & 18.5 \\
\hline
\end{tabular}

To the earing stage of winter wheat, the density of the weed population decreases markedly and the differences in pre-crops are eliminated. In addition to herbicides and their effective action, the reduction of weediness was also promoted by the powerful stem of winter wheat, which significantly worsened the conditions for development of weeds. The cleanest crops remained after the predecessor of winter rape. On this field, an average of $3 \mathrm{pcs} \cdot \mathrm{m}^{-2}$ of weeds is marked, after corn for grain, weed infestation is little different from the pre-crop, an average of $5 \mathrm{pcs} \cdot \mathrm{m}^{-2}$ of weeds; higher than winter rapeseed.

In the future, an increase in the weed component in the agrophytocenosis is noted. By full ripeness of winter wheat, this is due to the "lightening" of the crops due to the shrinkage of the leaf apparatus, when the crop no longer competes with the weeds and more favorable conditions are created for them. During this period, the number of weeds in crops after winter rape is 3.3 times less than after corn for grain and 2 times in comparison withsunflower.

The weed plant biomass also changed depending on the precursors and the phase of the culture development. During the tillering period, the highest weed mass was formed after the tilled precursors, which differed little in corn for grain and sunflower and varied between 98.9-89.7 $\mathrm{g} \cdot \mathrm{m}^{-2}$. In the winter wheat earing phase, the weight of the weeds was low and practically did not differ in their pre-crops. By full maturity of the crop, weed biomass increases, it is highest after corn for grain $81.3 \mathrm{~g} \cdot \mathrm{m}^{-2}$, and this is $67.4 \%$ higher than after winter rape and by $54.9 \%$ compared to sunflower.

In the end, pre-crops have an impact on such a productive indicator as the yield of winter wheat. Winter rapeseed, which was used as a control, provided maximum yield for the study period $5.21 \mathrm{t} \cdot \mathrm{ha}^{-1}$ (Table 3$)$.

Table 3

Influence of pre-crops on the yield of winter wheat

\begin{tabular}{|c|c|c|}
\hline Previous crop & Yield, $\mathbf{t} \cdot \mathbf{h a}^{-\mathbf{1}}$ & $\begin{array}{c}\text { Deviation from control, } \\
\mathbf{t} \cdot \mathbf{h a}^{\mathbf{-}}\end{array}$ \\
\hline Winter rapeseed & 5.21 & - \\
\hline Corn for grain & 4.34 & 0.87 \\
\hline Sunflower & 4.85 & 0.36 \\
\hline $\mathrm{HCP}_{05}$ & 0.31 & - \\
\hline
\end{tabular}


The placement of winter wheat after corn for grain and sunflower leads to a shortage of 0.36$0.87 \mathrm{t} \cdot \mathrm{ha}^{-1}$ of grain.

\section{Conclusions}

1. Pre-crops serve as a regulatory factor for soil and crop under the cultivation of winter wheat without tillage.

2. The earlier the pre-crop releases the field, the more intense the reduction of the potential of seeds in the upper soil layer to sowing of winter wheat. After winter rapeseed, the rate of this process increases by $26.6 \%$ compared with corn for grain and by $22.9 \%$ with sunflower.

3. Pre-crops have an impact on the amount and biomass of weeds during the growing season of winter wheat. A more contrasting difference in weediness of crops is manifested in the tillering stage of the crop, before the crops are treated with herbicides. Placing winter wheat in crop rotation after winter rapeseed helps reduce weed infestation by $34.1 \%$ compared with sunflower and by $47.1 \%$ with corn for grain.

4. The placement of winter wheat after winter rapeseed increases the grain yield by $0.36-0.87 \mathrm{t} \cdot \mathrm{ha}^{-1}$ compared with sunflower and corn for grain.

\section{References}

[1] Дридигер В.К., Дрепа Е. Б., Матвеев А. Г. Влияние технологии No-till на содержание продуктивной влаги и плотность чернозема выщелоченного Центрального Предкавказья (The influence of No-till technology on the content of productive moisture and the density of leached chernozem of the Central Ciscaucasia) // Современные проблемы науки и образования. 2015. № 1-2. 283 с. (In Russian).

[2] Meinel T., Grunwald L.-C., Akshalov K. Modern technologies for soil management and conservation in Northern Kazakhstan // Environmental Science and Engineering (Subseries: Environmental Science)Issue 202979. 2014. pp. 455-464.

[3] Perederieva V. M., Vlasova O.I., Volters I.A., Trubacheva L.V., Shutko A.P. Dynamics of agrofito-cenosissegetal' flora of winter wheat in long-term soil treatment // Research Journal of Pharmaceutical, Biological and Chemical Sciences. 2017. Vol. 8. №. 6. p. 782-786.

[4] Houšt' M., Procházková B., Hledík, P. Effect of different tillage intensity on yields and yieldforming factors in winter wheat //Acta Universitatis Agriculturae et Silviculturae Mendelianae Brunensis. 2012. 60 (5). pp. 89.

[5] Cordeau S., Smith R.G. Gallandt E.R. Timing of Tillage as a Driver of Weed Communities //WEED SCIENCE Vol. 65. issue 4. pp. 504-514.

[6] Schwarz J. Effect of different soil cultivation methods on the emergence of Aperaspica-venti // 28th German Conference on Weed Biology and Weed Control. A series of books: Julius-KuhnArchiv. 2018. Volume: 458. pp. 303-306.

[7] Васильев И.П., Туликов А.М., Баздырев Г.И. и др. Практикум поземледелию (Agronomy practice) / М.: Колос С, 2005. С. 253 (In Russian).

[8] Дридигер В. К., Попова Е.Л. Возделывание озимого рапса без обработки почвы на черноземе выщелоченном Центрального Предкавказья (Cultivation of winter rapeseed without tillage on leached chernozem of the Central Ciscaucasia) // Бюллетень Ставропольского научно-исследовательского института сельского хозяйства. 2014. № 6. С. 40-53(In Russian).

[9] Scheliga M., Petersen J. Seed potential and germination dynamic of Abutilon theophrasti in subsequent crops // 28th German Conference on Weed Biology and Weed Control. A series of books: Julius-Kuhn-Archiv, Germany. Volume: 458., 2018 pp. 427-434. 